\title{
THE BOVINE VIRAL DIARRHEA INDICATORS IN THE CATTLE ON THE BIG DAIRY FARMS IN SIBERIA
}

\section{A.G. GLOTOV, T.I. GLOTOVA, O.V. SEMENOVA, S.V. KOTENEVA, A.A. NIKONOVA}

Institute of Experimental Veterinary Science of Siberia and the Far East, Federal Agency of Scientific Organizations, pos. Krasnoobsk, PO box 463, Novosibirskii Region, Novosibirsk Province, 630501 Russia, e-mail glotov_vet@mail.ru, t-glotova@mail.ru, k-olga-83@mail.ru, koteneva-sv@mail.ru, Asenok2012@mail.ru Received March 25, 2016

\section{Abstract}

The Russian livestock industry, notably the dairy cattle industry, is currently facing serious changes. The number of large dairy farms, counting from up 1,500 dairy cows with an average annual milk production of about $12,000 \mathrm{~kg}$, is increasing. Extensive movement of animals from multiple sources bears the risk of introduction of infectious diseases including bovine viral diarrhea (BVD), an economically significant disease caused by BVD virus (BVDV). BVDV is a member of the Pestivirus genus of the family Flaviviridae, and presented the types 1 and 2 and cytopathic or noncytopathic biotypes. Infection of not immune to the virus heifers and cows results in an unsuccessful fertilization, repeated coming in heat, and, at early stages of pregnancy, in infertility, fetal mortality, abortion and stillbirth, arising due to the dysfunction of the ovaries, uterus inflammation and direct impact on the embryo. The pathogen also causes fetal immunotolerance infection, leading to the birth of persistently infected (PI) calves becoming permanent endogenous source of the pathogen in the herd. The aim of our work was to identify the main gender and age groups of cattle at the highest risk of virus infection to be a kind of indicators for type 1 BVDV circulation on dairy complexes. This research was carried out in 2006-2014 on Holstein-Friesian cows from six large dairy farms in Siberia (Tyumen region), where the specific prevention of the disease has not been conducted. Model age and gender groups of 100-400 cows were tested for the presence of PI animals. In this, the imported animals at quarantine and during the next 5 years were epizootically surveyed with regard to health parameters, morbidity, mortality, and gynaecologic pathology including repeated coming in heat, barrenness, abortion and stillbirth. Additionally, we used serological tests and PCR. It was found that up to $8.8 \%$ per 100 imported heifers were PI BVDV carriers at risk to produce PI calves. The first generation heifers respond to $71.4 \%$ seroconversion to the virus within 1-3 months after artificial insemination, and dry heifers are the most susceptible to infection. These animals may be an indicator of virus circulation in the dairy herd and the risk of producing PI calves. A total of $10.6 \%$ heifers, $8.8 \%$ dry heifers and $5.5 \%$ calves born from them were the PI carriers, which is higher than in cows of lactations 2 and 3. The portion of PI animals among these cows was $1.6 \%$, while in calves born from them it reached $3.7 \%$. For heifers, the virus genome was mostly detected in organs of aborted fetuses on months 4 to $6(40.0 \%)$ and 6 to $9(24.0 \%)$ of gestation, and in stillbirth calves $(29.2 \%)$. For cows, these parameters were $17.5 \%, 10.3 \%$ and $20.5 \%$, respectively. The frequency of viral RNA detection in the vaginal and uterine discharge amounted to $29.0 \%$ and $13.5 \%$, respectively. Thus, when importing animals for big dairy farms, mass reproductive problems occur for a certain period. Its duration depends on a number of factors. These are animal welfare, the time required for the herd formation, the number of incoming animals, the number of sources from which they have been delivered, the frequency of input of new heifers, the separation of pregnant cows from young animals, lack of vaccination, etc. Testing more susceptible animal groups in the herd may be helpful to establish the role of BVDV in the reproduction pathology.

Keywords: viral diarrhea-mucosal disease, cattle, heifer, dry heifers, cows, reproductive pathology, serological investigations, polymerase chain reaction

Currently, Russia is changing the strategy of dairy farming, increasing the share of farms producing milk, which contain 800 to 1,500 dairy cows, with an average annual productivity at about 9,000 to $12,000 \mathrm{l}$ of milk. In some regions, highly productive breeding cattle is being imported from abroad, and dairy farm complexes are completed only with imported livestock. Extensive and un- 
controlled flows of animals from multiple sources with unknown status pose a significant risk of introducing the causative agents of various infectious diseases, which would affect the economic performance of the herd. These include bovine viral diarrhoea (mucosal disease) (BVD MD) [1-2]. This infection is characterized by a variety of clinical signs [3-5], but its most significant adverse effects are reproductive disturbances accompanied by abortions, infertility and congenital fetal malformations [6-8], as well as the respiratory tract diseases of animals, which manifest as pneumonia [9-11].

The virus is a member of the Pestivirus genus of the family Flaviviridae, and comprises types 1 and 2 and two biotypes (cytopathic or non-cytopathic) [13, 14]. Currently, there are at least 16 subtypes of virus type 1, and 5 subtypes of virus type $2[15,16]$. Reproduction pathology can be caused by both types of the virus, although a non-cytopathic biotype of virus type 1 is more common [17].

Infection of non-immune heifers and cows results in fertilization failures [18], repeated coming in heat [19], while at early stages of pregnancy, it may lead to infertility, fetal mortality, abortions [20] and stillbirths, with all being caused by dysfunction of the ovaries, uterine inflammation or direct effects on the embryo [21, 22]. Abortions are grouped into four categories, such as 18-40, 40-125, 125-175 and 175 days until calving [23-25].

The most common acute, or transient, forms more often cause infection of animals of all ages with a non-cytopathic virus biotype. In this case, the incidence is high, but death rates are low. Virus isolation occurs only during the short-term viraemia (on days 10-12), and interrupts upon the beginning of antibody response, followed by the elimination of the virus from the body. Seroconversion is usually detected 3 to 12 weeks after infection. Convalescent animals produce lifelong immunity to the infecting virus type $[8,18]$.

The pathogen also causes immunotolerant fetal infections, leading to the birth of persistently infected (PI) calves who become a permanent endogenous source of the pathogen in the herd [25-26]. Many of them die before the age of 6 months, but some survive through to the adulthood and are used in the reproduction of the herd, which contributes to the continuity of epizootic process [27-29]. High seropositive rates in the most susceptible to the viral infection age-sex groups suggest its circulation in the herd, as well as the presence of PI animals [24, 30].

Therefore, the identification of specific age-sex groups of animals, who are at the greatest risk of infection with the virus and serve as markers of the virus circulation in the herd, is of great importance in the development of effective infection control programs

Considering the above, the identification of specific age-sex groups of animals, who are at the greatest risk of infection with the virus and serve as markers of the virus circulation in the herd, is of great importance in the development of effective infection control programs

In this paper, we first found, that the first generation heifers and bred heifers are the most susceptible to BVD-MD infection among the animals imported to the domestic dairy farm complexes. The number of PI animals among the second and third calving heifers and their calves is greatly reduced.

Our objective was to identify major age-sex groups of animals serving as markers of the circulation of the bovine viral diarrhoea (mucosal disease) causative agent, virus type 1, in the reproductive pathology in dairy farm complexes in Siberia, completed with the imported livestock.

Technique. The study was performed in 2006-2014 in a setting of six large dairy farm complexes in Siberia (Tyumen region), where specific prophylaxis was not carried out. Tthe livestock in the complexes consisted of 800 or more Holstein-Friesian cows with the annual average productivity at 7,000 - 
10,0001 or more. Animals were housed in year-round dry sralls. Feeding and keeping were consistent with physiological and zootechnical standards. The presence of PI animals was identified using pattern groups of 100-400 animals.

The imported animals at quarantine and during the next 5 years were epizootically surveyed with regard to general health parameters, morbidity, mortality, and gynaecologic pathology (including repeated coming in heat, infertility, abortions, and stillbirths).

Blood samples were collected one time for serological screening, and two times, with a 4-6 week interval, for the BVD-MS retrospective diagnosis. Neutralization test was performed using 3,097 serum samples, including 351 from bred heifers in the service, 320 from first-calf heifers, 500 from heifers after artificial insemination, 350 from cows in the service, 260 from cows after calving, and 1,316 from first- to second-lactated cows. The test was performed by a microtechnique on a continuous line of Madin-Darby bovine kidney (MDBK) cells according to the standard by the Office International des Epizootics (OIE, 2015), using the NADL cytopathogenic strain as an antigen

Biomaterial was tested by the reverse transcription polymerase chain reaction (RT-PCR) using an in-house testing kit and protocol. The biomaterial included 102 samples of bull semen, 589 samples of vaginal and uterine discharges (including 352 from first-calf heifers and 237 from cows after calving), 270 samples of visceral organs (including 87 from aborted 4 to 6-month fetuses, 79 from aborted 6 to 9-month fetuses, 104 from stillborn calves). The PI animals were detected by testing 3,740 paired sera from first-calf heifers, bred heifers, cows and calves, obtained at 4-6 week intervals. To exclude the acute form of the infection, individual samples, which gave positive results in the first test series, were retested after 4-6 weeks. Persistent infection was diagnosed only when viral RNA was found in serum samples in duplicate.

The data were processed by standard methods [31] using Statistica 6.0 software package (StatSoft Inc., USA), with an estimation of statistical significance $(\mathrm{p} \leq 0.05)$ for a $95 \%$ confidence level $\left(\mathrm{I}_{95}\right)$.

Results. Upon arrival at the diary complexes, bred heifers had elevated titers of virus neutralizing antibody to the BVD-MD virus, and a seropositivity level averaged to $85-95 \%$. During the first 6 months, abortions, stillborn calves (up to $25 \%$ of the imported bred heifers) were usually registered, as well as signs of gastrointestinal and respiratory diseases in calves aged up to 30 days. Thus, during the first 3 months, 74 of 800 pedigree bred heifers delivered from one of the European countries undergone abortions, 84 calves were born dead and 45 calves died before the age of 1 month due to diarrhea and respiratory diseases. Moreover, we observed, with further bred heifers' calving and local insemination, low fertility, early embryonic mortality, abortions, birth of dead or weak calves, endometritis, transient decline in milk production, diseases of calves under 6 months of age, and lengthening of the service period.

Tests of the bull sperm used for insemination of the breeding stock were negative, which suggested the presence of an endogenous source of the pathogen in the studied herds, i.e. the presence of PI animals as well as animals with acute infection.

During 3-5 years after the importation, seropositivity rates in the first generation heifers after artificial insemination were high and averaged up to $89.4 \%$, with $71.4 \%$ of them responded by 64 - to 128 -fold seroconversion to the pathogen in 1-3 months after the insemination. That was probably due to the primary contact with the virus. These values in first and second lactation cows were lower and amounted to $36.5 \%$.

Seropositivity rates in the bred heifers and cows in the service, as well as 
after calving were similar. The proportion which responded with seroconversion to the virus was $14.6 \%$ in bred heifers, $29.0 \%$ in heifers and $12.6 \%$ in cows after calving. There were no increase in the viral antibody titers observed in cows in the service. Mean titers of specific antibodies were higher in heifers 30-90 days after the artificial insemination compared to other categories of animals and reached up to $9.6 \pm 0.1 \lg _{2}$.

On average, the viral genome was found in $15.6 \%$ of samples. The PI proportion was $10.6 \%$ for heifers after insemination, $8.8 \%$ for bred heifers in the service, $5.5 \%$ for calves born to them (see Table). It should be noted that because of the large number of animals the study did not include the entire livestock, but only the pattern groups, therefore, mean values in the whole herd may be higher. It was found that, at the animal arrival, there may be on average $8.8 \%$ of the PI virus carriers per each imported batch of 100 bred heifers.

Frequency rates of detecting the genome of the causative agent of bovine viral diarrhea (mucosal disease) in the biomaterial from highly productive Holstein-Friesian animals on large dairy farm complexes (Tyumen region, 2006-2014)

\begin{tabular}{|c|c|c|c|c|}
\hline \multirow{2}{*}{ Category of animals } & \multirow{2}{*}{ Biomaterial } & \multirow[b]{2}{*}{$n$} & \multicolumn{2}{|c|}{ Positive samples found } \\
\hline & & & total & of samples tested, \% \\
\hline \multicolumn{5}{|c|}{ Bred heifers and first-calf heifers } \\
\hline Heifers after insemination & Blood serum & 500 & 53 & 10.6 \\
\hline Bred heifers in the service & Blood serum & 351 & 31 & 8.8 \\
\hline Newborn calves & & & & \\
\hline before colostrum rearing & Blood serum & 400 & 22 & 5.5 \\
\hline First-calf heifers, including & Blood serum & 320 & 72 & 22.5 \\
\hline after abortion & Vaginal and uterine discharges & 352 & 102 & 29.0 \\
\hline 4- to 6-month aborted fetus & Visceral organs & 30 & 12 & 40.0 \\
\hline 6- to 9-month aborted fetus & Visceral organs & 50 & 12 & 24.0 \\
\hline Stillborn calves & Visceral organs & 65 & 19 & 29.2 \\
\hline Total & & 2068 & 323 & 15.6 \\
\hline \multicolumn{5}{|c|}{ Cow s } \\
\hline Cows in the service & Blood serum & 1926 & 31 & 1.6 \\
\hline Cows after calving & \multicolumn{4}{|l|}{ Vaginal and uterine discharges } \\
\hline incl. after abortion & & 237 & 32 & 13.5 \\
\hline Newborn calves & & & & \\
\hline before colostrum rearing & Blood serum & 243 & 9 & 3.7 \\
\hline 4- to 6-month aborted fetus & Visceral organs & 57 & 10 & 17.5 \\
\hline 6- to 9-month aborted fetus & Visceral organs & 29 & 3 & 10.3 \\
\hline Stillborn calves & Visceral organs & 39 & 8 & 20.5 \\
\hline Total & & 2531 & 93 & 3.7 \\
\hline
\end{tabular}

The viral genome was found on average in $40.0 \%$ of 4 - to 6-month aborted fetuses, $24.0 \%$ of 6 - to 9-month aborted fetuses, and $29.2 \%$ of stillborn calves. The viral genome was localized in lymphoid tissue, parenchymatous organs and the brain. A hydrocephalus was more often observed in the 4- to 6month aborted fetuses, while live births were presented with curly coat, or lack thereof, congenital cataract and joint disease. In most cases, seroconversion to the virus was detected in the mothers 6-8 weeks after the abortion. In first-calf heifers, the virus was found in $29.0 \%$ of vaginal and uterine discharges.

Mean rate of the virus detection in first and second lactation cows was $3.7 \%$, which was $12.9 \%$ lower than in first-calf heifers. The number of PI animals among the cows was $1.6 \%$ and among the calves before colostrum rearing $3.7 \%$, which was also lower than that in heifers and calves born to them, i.e. by $9.0 \%$ and $5.1 \%$, respectively (see Table).

The pathogen genome was found in the visceral organs in $17.5 \%$ of 4to 6-month aborted fetuses, $10.3 \%$ of 6 - to 9-month aborted fetuses and $20.5 \%$ of stillborn calves. The virus was found in $13.5 \%$ of vaginal and uterine discharges from cows presented with signs of acute endometritis, including the aborted ones.

Large-scale reproductive disorders in the imported animals were revealed within a relatively short period (up to 6 months) during the establishment of 
dairy farm complexes. In addition to the transport stress, these were due to the presence of the PI bred heifers that infected other animals in the group during the transportation and upon arrival in the importing country. Such PI bred heifers are at risk of delivering the PI offspring that in turn becomes a constant source of endogenous virus for calves and breeding stock in the herd. This period could be prolonged for up to 2-3 years, depending on the animal husbandry, their placement, stocking duration, the premises, the number of incoming animals and the sources they were brought from, the frequency of the introduction of new animals, joint housing of pregnant animals with young ones, and lack of specific prophylaxis.

As soon as the proportion of animals who developed immunity to the virus began to increase, both the number of animals susceptible to infection and the disease incidence were reduced. Consequently, the disease manifestations changed over time (frequency rates of reproductive abnormalities decreased, while disease incidence in calves increased). However, a permanent endogenous source of the pathogen suggested the continuity of epizootic process, which created fixed foci of concern for BVD-MD with a low incidence of reproductive pathology.

A mother-calf closed cycle greatly contributes to the formation of a fixed concern for BVD-MD and the continuity of epizootic process, leading to the birth of persistently infected offspring. Determination of markers of the pathogen active circulation in the herd plays an important role in the planning and implementing the disease control programs.

Thus, we identified major age-sex groups of animals who may serve as indicators or markers, and reflect the circulation of the bovine viral diarrhoea (mucosal disease) (BVD-MD) causative agent in dairy farm complexes, completed with the highly productive imported livestock. At the arrival of animals, there may be on average $8.8 \%$ of persistently infected (PI) virus carriers and $5.5 \%$ of PI calves born to them per each batch of 100 bred heifers. During the follow-up years, the first generation heifers (with $71.4 \%$ of them responding by seroconversion to the virus 1-3 months after artificial insemination) and bred heifers are the most susceptible to infection. These rates may be indicative of virus circulation in the dairy herd and the risk of birth of PI calves, which would serve as a permanent source of infection. The number of PI animals among the second and third calving heifers and the calves they born is greatly reduced with an increase in the immune status of the herd. However, the presence of a permanent endogenous source of the pathogen in the herd leads to farms with stable status of BVD-MS concern, manifested in maintaining the virus circulation, which, although with a relatively low frequency, poses a threat to the emergence and spread of reproductive disorders, reducing the economic performance of a dairy herd. Diagnostic testing of the most susceptible to infection animal groups is required to establish the role of the virus in the reproduction pathology. These groups must be considered in epizootical surveys of the herds aimed to evaluation of their infection status, development of the regional infection control programs, selection of appropriate vaccines and optimal regimes of their administration, in order to reduce the circulation of the virus in susceptible animals.

\section{REFERENCES}

1. Glotov A.G., Kelling K.L. Rossiiskii veterinarnyi zhurnal. Sel'skokhozyaistvennye zhivotnye, 2007, 4: 19-22 (in Russ.).

2. OIE. Manual of diagnostic tests and vaccines for terrestrial animals. P. 2, S. 2.4. Ch. 2.4.8. Bovine viral diarrhoea. Paris, France, 2015.

3. Yurov K.P., Anoyatbekova A.M., Dias Khimenes K.A., Alekseenkova S.V. Veterinariya, 2015, 9: 3-8 (in Russ.). 
4. H o u e H. Epidemiological features and economical importance of bovine virus diarrhoea virus (BVDV) infections. Vet. Microbiol., 1999, 64: 89-107 (doi: 10.1016/S0378-1135(98)00262-4).

5. Almeid a L.L., M i randa I.C.S., He in H.E., S a ntiago N.W., Cost a E.F., Marks F.S., Rodenbusch C.R., C a nal C.W., Corbellini L.G. Herd-level risk factors for bovine viral diarrhea virus infection in dairy herds from Southern Brazil. Res. Vet. Sci., 2013, 93: 901-907 (doi: 10.1016/j.rvsc.2013.08.009).

6. Glotov A.G., G lotova T.I. Veterinariya, 2015, 4: 3-8 (in Russ.).

7. G a t e s M.C., W o o 1 h o u s e M.E., Gu n n G.J., H u m p h r R.W. Relative associations of cattle movements, local spread, and biosecurity with bovine viral diarrhoea virus (BVDV) seropositivity in beef and dairy herds. Prev. Vet. Med., 2013, 112(3-4): 285-295 (doi: 10.1016/j.prevetmed.2013.07.017).

8. Ridpath J.F. Bovine viral diarrhea virus: global status. Vet. Clin. North. Am. Food Anim. Pract., 2010, 26(1): 105-121 (doi: 10.1016/j.cvfa.2009.10.007).

9. Glotov A.G., Glotova T.I., Petrova O.G., Nefedchenko A.V., T at a r c huk A.T., Kot e neva S.V., Vetrov G.V., S e rge e v A.N. Veterinariya, 2002, 3: 17-21 (in Russ.).

10. Zhidk ov S.A., L e b e d e v A.I., G o g o lev M.M. Vestnik Rossiiskoi akademii sel'skokhozyaistvennykh nauk, 1995, 3: 50-53 (in Russ.).

11. Chaves N.P., B e z e r ra D.C., S o u s a V.E., S a n t o s H.P., P e r e i r a H.M. Frequency of antibodies and risk factors of bovine viral diarrhea virus infection in non-vaccinated dairy cows in the Maranhense Amazon region, Brazilfonte 10. Ciencia Rural, 2010, 40: 1448-1451 (doi: 10.1590/S0103-84782010005000089).

12. Virus Taxonomy: 2015 Release. Available http://ictvonline.org/virusTaxonomy.asp. Accessed March 15, 2016.

13. Ridp ath J.F., B olin S.R. Differentiation of types 1a, $1 \mathrm{~b}$ and 2 bovine viral diarrhea virus (BVDV) by PCR. Mol. Cell. Probes, 1998, 12(2): 101-106 (doi: 10.1006/mcpr.1998.0158).

14. Ridpath J.F. Bovine viral diarrhea virus: global status. Vet. Clin. North. Am. Food Anim. Pract., 2010, 26(1): 105-121 (doi: 10.1016/j.cvfa.2009.10.007).

15. Giangaspero M., Apicellab S., Haras awa R. Numerical taxonomy of the genus Pestivirus: New software for genotyping based on the palindromic nucleotide substitutions method. J. Virol. Methods, 2013, 192: 59-67 (doi: 10.1016/j.jviromet.2013.04.023).

16. G i a n g a s p ro M., H a r a s a w a R. Characterization of genotypes among bovine viral diarrhea virus type1 strains according to palindromic nucleotide substitutions in the genomic 5' untranslated region. J. Virol. Methods, 2014, 195: 34-53 (doi: 10.1016/j.jviromet.2013.10.003).

17. Eve rm a n J.F., Rid p at h J.F. Clinical and epidemiologic observations of bovine viral diarrhea virus in the northwestern United States. Vet. Microbiol., 2002, 89: 129-139 (doi: 10.1016/S0378-1135(02)00178-5).

18. Gonzalez Alta miranda E.A., Ka ise r G.G., Mucci N.C., Verna A.E., C a m pe ro C.M., O d e y n A.C. Effect of Bovine Viral Diarrhea Virus on the ovarian functionality and in vitro reproductive performance of persistently infected heifers. Vet. Microbiol., 2013, 165: 326-332 (doi: 10.1016/j.vetmic.2013.04.007).

19. G ro o ms D.L. Reproductive consequences of infection with bovine viral diarrhea virus. Vet. Clin. North. Am. Food Anim. Pract., 2004, 20: 5-19 (doi: 10.1016/j.cvfa.2003.11.006).

20. M c Gowan M.R., Ki rk la nd P.D. Early reproductive loss due to bovine pestivirus infection. Brit. Vet. J., 1995, 151: 263-270.

21. Munoz-Z anzi C.A., Thurmond M.C., H i e t a la S.K. Effect of bovine viral diarrhea virus infection on fertility of dairy heifers. Theriogenology, 2004, 61: 1085-1099 (doi: 10.1016/j.theriogenology.2003.06.003).

22. Fray M.D., Mann G.E., Clarke M.C., Charlest o n B. Bovine viral diarrhea virus: its effects on ovarian function in the cow. Vet. Microbiol., 2000, 77: 185-194.

23. G at e s M.C., H u m p h r R.W., G u n n G.J. Associations between bovine viral diarrhoea virus (BVDV) seropositivity and performance indicators in beef suckler and dairy herds. Vet. J., 2013, 198: 631-637 (doi: 10.1016/j.tvjl.2013.09.017).

24. Ke 11 ing C.L., Top 1 iff C.L. Bovine maternal, fetal and neonatal responses to bovine viral diarrhea virus infections. Biologicals, 2013, 41: 20-25 (doi: 10.1016/j.biologicals.2012.09.006).

25. Kelling C.L., Grote 1 u e s che n D.M., S m it h D.R., B roderse n B.W. Testing and management strategies for effective beef and dairy herd BVDV biosecurity programs. The Bovine Practitioner, 2000, 34: 13-22.

26. Li ndberg A.L.E., A lenius S. Principles for eradication of bovine viral diarrhea virus (BVDV) infections in cattle populations. Vet. Microbiol., 1999, 64: 197-222 (doi: 10.1016/S03781135(98)00270-3).

27. Luzzago C., Frige rio M., P i c cinini R., Dap ra V., Ze c coni A. A scoring system for risk assessment of the introduction and spread of bovine viral diarrhoea virus in dairy herds in Northern Italy. Vet. J., 2008, 177: 236-241 (doi: 10.1016/j.tvjl.2007.04.017). 
28. Rodning S.P., Givens M.D., Marley M.S.D., Zhang Y., Riddell K.P., Gali k P.K., H a th c ock T.L., Gard J.A., Prevat t J.W., Ow s ley W.F. Reproductive and economic impact following controlled introduction of cattle persistently infected with bovine viral diarrhea virus into a naive group of heifers. Theriogenology, 2012, 78: 1508-1516 (doi: 10.1016/j.theriogenology.2012.05.031).

29. Vi et A.F., Fouri chon C., S e e gers H. Review and critical discussion of assumptions and modeling options to study the spread of the bovine viral diarrhea virus (BVDV) within a cattle herd. Epidemiol. Infect., 2007, 135(5): 706-721 (doi: 10.1017/S095026880600745X).

30. Humphry R.W., Brülisauer F., Mc Kendrick I.J., Nettleton P.F., Gun n G.J. Prevalence of antibodies to bovine viral diarrhoea virus in bulk tank milk and associated risk factors in Scottish dairy herds. Vet. Rec., 2012, 171(18): 445 (doi: 10.1136/vr.100542).

31. Z a k s L. Statisticheskoe otsenivanie [Statistical estimation]. Moscow, 1976 (in Russ.). 